\title{
G306
}

\section{針刺し・切創予防技術教育における損傷疫学理論とシミュレーションを 用いた研修手法の開発}

\author{
吉川＼cjkstart徹 1,2 、柴田＼cjkstart清2,3 \\ 1財団法人 労働科学研究所 研究部 ヒューマンケアサービス研究グループ、職業感染制御研究会、 3 東 \\ 京都看護協会感染管理認定看護師養成課程
}

【目的】損傷予防（Injury Prevention）理論に基づ く労働現場の災害防止アプローチを医療従事者へ の針刺し切創予防技術教育に応用し、損傷疫学理 論とシミュレーションを用いた研修手法の開発を 試みる。【方法】The Johns Hopkins Center for Injury Research and Policyで実施されている損 傷疫学理論と対策指向型グループリスク評価を用 いた問題解決型損傷予防研修手法を、東京都看護 協会感染管理認定看護師養成課程（研修生 25 名） に打ける針刺し切創予防技術教育（職業感染管理 の一部）に応用した。1）損傷疫学理論に基づく針 刺し切創サーベイランス結果の提示、2) 具体的な 針刺し・切創事例と病院内での問題場面の設定、課 題の提示、3) 対策指向グループ作業による解決策 の検討というシミュレーションを分散 2 日の研修 日程に設定した（表 1)。サーベイランスデータの

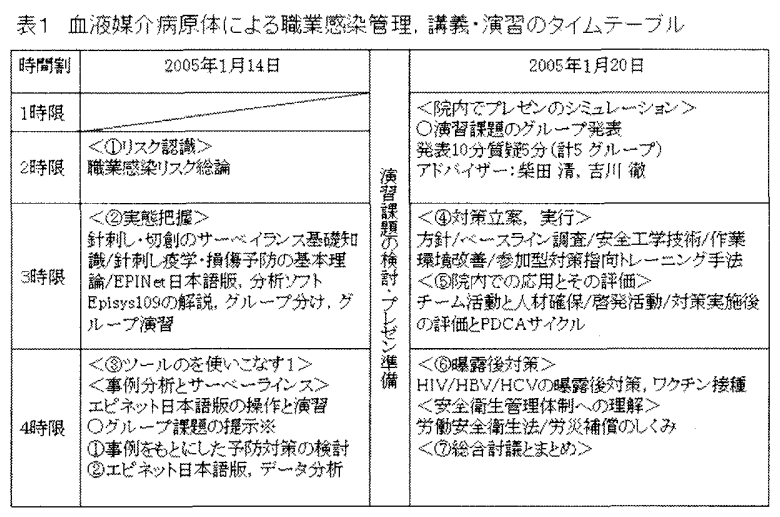

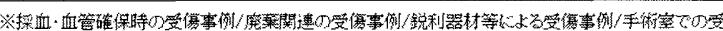

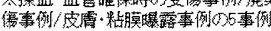

利用、グループワーク形式の学習手法などについ て研修参加者への質問紙調查により評価した。講 義・演習扔よび評価は平成 17 年 1 月に実施した。 本手法の利点と制約について検討した。【結果】問 題解決型損傷予防研修手法は損傷事例 (災害事例) を針刺し・切創事例に置き換え分散 2 日の研修に 設定可能であった。質問紙調査結果 (回答 24 名、回 収率：96\%)では、サーベイランス結果を利用した グループ演習（討議・発表）はとくに評価が高かっ た（大変参考になった $(75 \%) 、$ 参考になった $(25 \%))$ 。自由記入でも、1)実際の具体的事例を用 いたグループワークによる対策検討がとても有用 (11 件)、2)研修資料が充実、現場で使えるツール の入手が有用 (7 件)、3)サーベイランスツール (エ ピネット日本語版）の利用法と操作法が有用（6 件)などがあげられた。一方、シミュレーションで 検討した事例を実際の病院で応用寸る際は、感染 管理チームの存在、安全衛生委員会の強化、トップ の理解、低コス卜対策、デー夕評価結果の活用ノウ 八ウの強化などが不可欠との意見があった。【考 察】1）参加型で行なうグループ形式による実践重 視型の事例検討の方法は評価が高く、サーベイラ ンスと対策指向型リスク評価のシミュレーション が重要と考えられた。2) 今回は受講者の主観的満 足度を中心とした評価で、研修の有効性について は今後研修受講者のフォローアップ評価が必要で ある。今後、分散講義日程の設定と実践的問題解決 型研修がより実施されることが期待される。 